\title{
2010
}

Working Paper

(1)

INSTITUTO DE POLÍTIGAS Y BIENES PÚBLIGOS [IPP]

\section{Negotiating THE PAST: CLAIMS FOR RECOGNITION AND POLICIES OF MEMORY IN THE EU}

\author{
Carlos Closa
}

CONSEJO SUPERIOR DE INVESTIGACIONES CiENTÍFICAS (CSIC)

Institute of Public Goods And Policies (IPP)
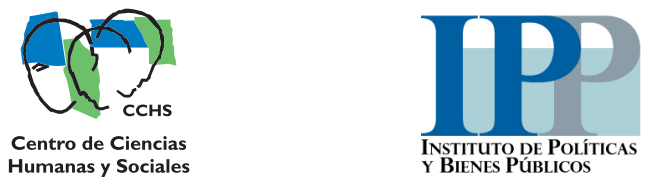


\section{INSTITUTO DE POLÍTICAS Y BIENES PÚBLICOS, CCHS-CSIC}

\section{Copyright $($ C2010. Closa, C. All Rights reserved.}

Do not quote or cite without permission from the author.

Instituto de Políticas y Bienes Públicos

Centro de Ciencias Humanas y Sociales

Consejo Superior de Investigaciones Científicas

C/ Albasanz, 26-28.

28037 Madrid (España)

Tel: +34 916022300

Fax: +34 913045710

http://www.ipp.csic.es/

The working papers are produced by Spanish National Research Council - Institute of Public Goods and Policies and are to be circulated for discussion purposes only. Their contents should be considered to be preliminary. The papers are expected to be published in due course, in a revised form and should not be quoted without the authors' permission.

\section{How to quote or cite this document:}

Closa, C. (2010). Negotiating the Past: Claims for Recognition and Policies of Memory in the EU. Instituto de Políticas y Bienes Públicos(IPP), CCHS-CSIC,Working Paper, Number 8.

Available: http://hdl.handle.net/10261/24430 


\title{
Negotiating The PAST: Claims FOR RECOGNITION AND POLICIES OF MEMORY IN THE EU
}

\author{
Carlos Closa Montero \\ CONSEJO SUPERIOR DE INVESTIGACIONES CIENTÍFICAS (CSIC) \\ Institute of Public GoOds AND POLICIES (IPP-CCHS) \\ CARLOS.CLOSA@CCHS.CSIC.ES
}

\begin{abstract}
During the last years, several subjects have advanced claims for developing within the EU specific elements of what is often referred to as policies of memory. Whilst this trend could be perceived as one more instance of transference of domestic issues to the EU level, the distinctive trait of these claims is that claims on memory are associated both to justice and identity and, hence, they appeal to an underlying structure of normative justification. This paper examines these claims and discusses the normative argument supporting them. The argument revises, firstly, what are the policies of memory and, secondly, it discusses the relation between policies and politics towards the past in order to unveil the subjective component associated to recognition. The subjective dimension of recognition paves the way for asserting the location of victims as the most legitimate bearer of claims for recognition. The third section describes the very limited policies and politics of memory in the EU in order to enter, fourthly, into a deeper analysis of the new claims emerging in the post 2004 scenery. The argument elaborates then a theoretical frame which draws on the notion of "recognition order" of Honneth in order to establish the normative foundation for EU policies of memory. Being the EU a recognition order, claims referring memory cannot be legitimately excluded from the EU agenda. Nevertheless, legitimacy of claims for recognition does not mean that policies and proposals linked to these claims have automatic validity. Rather, policies must derive from EU wide deliberation on the claims and the proper policies to pursue having in mind a number of requirements. The conclusion sums up the argument.
\end{abstract}

\section{CONTENTS}

1. WHAT ARE THE POLICIES OF MEMORY? .3

2. POLITICS OF MEMORY: CLAIMS FOR RECOGNITION AND PARTISAN USES..............................6

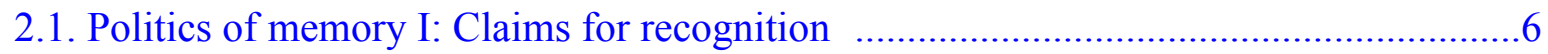

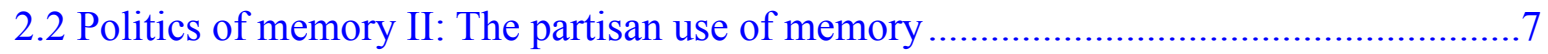

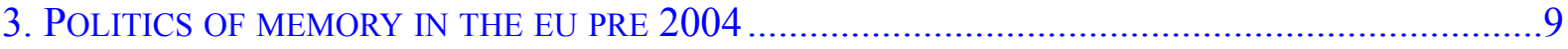

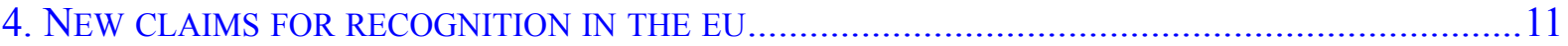

5. STRUGGLING FOR RECOGNITION: A NORMATIVE ARGUMENT FOR EU POLICIES OF MEMORY 17

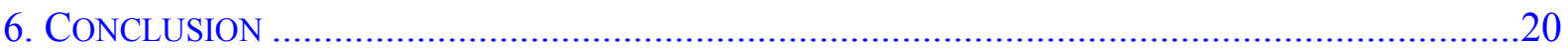

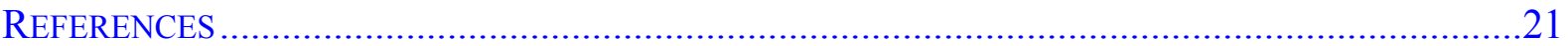




\section{WHAT ARE THE POLICIES OF MEMORY?}

Policies of memory refer to a specific variety or sub-type of policies towards the past or policies of history. Policies towards the past comprise all procedures, means and instruments for the selection, preservation and interpretation of facts from the past that are meaningful within a given political setting or community. ${ }^{1}$ They exist in order to satisfy a moral requirement: they provide meaning to the past in terms which are meaningful for the current self-understanding of the community. Moral requirement and current self-understanding determine two basic traits of any policy towards the past (including of course policies of memory): they are contextually meaningful and they are selective. Facts are meaningful in the context of given community although certain facts (being the Holocaust the obvious example) may acquire universal significance. As for the selective dimension, not all past facts are meaningful nowadays and not all of them are meaningful in the same form. Selection tends to be biased and not neutral: facts that portray successes, heroism and a positive view of the community are more prone to be selected that negative facts. ${ }^{2}$ But even these negative facts (for instance, defeats) may play a role in glorifying the community or justifying its existence.

All political communities with a degree of political organizations implement some kind of policies towards the past not least because they fulfil a key function in identity building: by identifying facts in the past that are meaningful in the current moral self-understanding of the community, they establish continuity through time. Past facts (narrated and/or re-interpreted) serve to re-create the community and give it a sense of coherence. Understanding the past and its demands on the present is precisely the function that nationally conscious individuals perform by means of a "collective, national memory" (Snyder: 2004: 50). Myths, facts, symbols, suffering and heroism, repression and fate provide elements for representing the community through time and setting temporal yardsticks for identification. Naturally, when facts of the past and/or their meaning in the current self-understanding of the community and/or the community itself are disputed, policies turn into politics.

Naturally, the term past used until here is a very imprecise one that brings together "history" and "memory". Tracing the difference between these two terms serves also to differentiate between policies of the past (or towards the past) or policies of history, on the one hand, and policies of memory, on the other. ${ }^{3}$ These differences are the existing between "past", "history"

1 Droit refers to the ensemble of political, juridical, symbolic measures implemented by states and the work of memory assumed by actors of civil society (Droit; 2007: 102)

2 In this line, Stråth argues: collective memory is 'the result of a selective process of remembering and forgetting the past' and only exists where there is a group that remembers. The construction of a collective memory interacts with deep-rooted myths of the national community (Stráth; 2005: 260).

3 Aguilar defines policies of memory as "public (not necessarily political) initiatives which aim at diffusing or consolidating a given interpretation of a past event which has great relevance for certain social and/or political groups or for the whole of the country" (Aguilar; 2008: 53). This definition leaves indeterminate the time frame to which memory refers: a past event covers anything between yesterday and prehistory. Contrariwise, this paper 
and "memory". Difficulties for comprehension appear because very often the word "memory" is used meaning exactly past or history. Used in this way, policies of the past and policies of memory mean the same. Conflating past/history in general, and memory, in particular, happens commonly because procedures for dealing personally with both are similar: remembering and learning. Tony Judt argues that unlike memory, which confirms and reinforces itself, history contributes to the disenchantment of the world (Judt; 2005: 830). Judt's argument is pointing in the direction of distinguishing between objective facts and subjective recollection even though this may be considered a thin one. But if the subjective/objective dimension is combined with a time frame, then differences may appear more clearly: memory implies that people communicate historical events and facts as part of their living experience or as part of the personal experience immediately transmitted to them by other live persons. In a real sense, it is erroneous to speak of memory when people alive in a giving community cannot communicate historical facts as part of their living experience or as part of the living experience personally convey to them by live (at the time the experiences were conveyed) relatives or acquaintances. Personal experience and personal involvement are part of memory.

Adhering strictly to this distinction allows differentiating between historical facts and facts of memory even accepting that the first may (or may not) include subjective elements. For instance, the American Civil War is a historical fact in the sense that no member of generations alive may have direct personal experiences of the event. It nevertheless may incorporate subjective referents in the form in which different people may interpret nowadays the facts and their significance for the community. On the contrary, the Vietnam War may be rightly perceived as a fact of memory additionally to its historical value in the sense that forms part of the living experience of some of the current generations. Naturally, the temporal frontier between both categories is difficult to precise.

Additionally, the collective significance of individual memories derives from their intersubjective dimension: individual memories of those who have directly lived an event contribute to the creation of a shared narrative when they interact with other individuals with which share same social or cultural adscription (Aguilar; 2008: 62). The transmission of these shared narratives (which Aguilar calls collective or social memory) to the forthcoming generations transforms them into historical memory (Aguilar; 2008: 62).

The transmission of narratives, memories, myths, etc. which are not strictly part of memory relies greatly on explicit (or implicit) policies of memory; i.e. policies that have the function of transferring through time narratives on facts filtered by specific community preferences. Among these policies, some are memory-specific (i.e. policies designed with the only finality

relates memory to personal subjective experience of past events. Implicitly, though, Aguilar distinguishes intuitively the subjective from the non subjective significance of past time and she uses for this purpose the reference to generations. 
of transferring narratives about the past) and some are non specific (i.e. policies which have different functions but fulfil also indirectly a memorialising function). Among specific policies, policies of symbols are probably the most prolific arena for policies of memory and they involve both material symbols (such as monuments and memorials) and immaterial symbols, such as rituals and celebrations (commemoration dates and the way commemoration is made). Awareness policies refer to initiatives to underline and emphasize the importance of certain facts or events. The specific instruments for these measures are very varied, involving films, exhibitions, conferences and seminars, etc. However, the most important policy of memory is a non-specific one: education policy which may as policy of memory through two different subjects; history and civic education. Teaching of history (and eventually geography) highlights specific historic facts and it contributes towards the creation of identity by projecting retrospectively the perception of the community in specific historical moments. Tracing these and recovering them creates a sense of continuity through time. In the field of education, a policy of memory can be indifferently constructed on facts selected which ether exalt the existing community (glorifying its successes) or underline their suffering and oppression.

States do normally posses a large number of policies through which a specific policy of memory can be implemented. In contrast (and before discussing the justification for these), it must be underlined that the EU has very scarce formal competences in the areas in which policies of memory can be constructed. On education (article 165.2 Consolidated version of the Treaty on the Functioning of the European Union), the Treaty establishes that the Union action shall be aimed at developing the European dimension in education but fully respecting the responsibility of the Member States for the content of teaching and the organisation of education systems (article 165.1). On culture (article 167.2), the treaty establishes that action by the Union shall be aimed at encouraging cooperation between Member States and, if necessary, supporting and supplementing their action in the following areas: improvement of the knowledge and dissemination of the culture and history of the European peoples and conservation and safeguarding of cultural heritage of European significance. Noticeably, the elimination of article I-8 of the EU Constitutional Treaty in the Lisbon Treaty provides a clue on the understanding that Member States assign to EU symbolic policies: whilst the elimination did not aim at an specific memorialisation content (such as the reference contained in the article to the date of $9^{\text {th }}$ May), it questioned the explicit attempt to construct a symbolic dimension at all. The Stockholm Programme confirmed this approach: Each Member State has its own approach towards dealing with serious wrongdoing of repressive regime but, in the interests of reconciliation, the memory of those crimes must be a collective memory, shared and promoted, where possible, by us all. The Union must play the role of facilitator. ${ }^{4}$

4 The Stockholm Programme - An open and secure Europe serving and protecting the citizens. Brussels, 2 December 2009. 


\section{POLITICS OF MEMORY: CLAIMS FOR RECOGNITION AND PARTISAN USES}

Having established what policies of memory are, next step is unveiling how they are constructed, i.e. what are the politics behind policies? What constitutes collective memory and what is consigned to collective oblivion, in other words, taboos and what we do not talk about, is a highly disputed question, which reflects power relations in the definition of social problems (Stråth; 2005: 257). For this, attention is paid to two different kinds of arguments: a normative and practical one which examines the claims made for recognising memory and a purely practical one which ponders the instrumental use of policies of memory.

\subsection{Politics of memory I: Claims for recognition}

The interaction between individual memories of experiences may not reach the level of public policy. The transition from interactive dimension to policies occurs when the subjects of memory make claims for recognition. Recognition is constitutive of subjectivity; one becomes an individual subject by virtue of recognition, and being recognised by, another subject (Fraser; 2003: 10). Thus, when subjects claim the recognition of their subjective memories, they are demanding from the policy their full consideration as individuals by accepting personal experiences that determines deeply their subjectivity. For Fraser, recognition implies selfrespect, self-esteem and self-confidence. Recognition of memory in a given community restores persons' dignity by means of policies which take into account their claims. Recognition thus, is an essential component of policies of memory and politics of memory are the struggles for recognition of memory claims.

In a descriptive sense, several subjects may enter the political arena with different claims for recognition of memory. Claimants aim at policies recognising their memory experiences. Now, moving to a normative standpoint, this requires identifying the criteria that determines which are the legitimate claims for recognition of personal experiences. Naturally, the legitimacy of claims for recognition depends on the type of regime. Policies of memory happen both in democratic and non democratic polities. In fact, repressive regimes use intensively instruments such as education and symbolic policies. In empirical terms, there may not be substantive differences in the way either democratic and repressive regimes dealt with the issues of past and memory, but in normative terms, a deep difference emerge: democratic politics of memory must be compatible with the genetic code of democracy, implying human rights, rule of law and rulers' accountability. Policies of memory in democratic policies necessarily require establishing compatibility between moral standards of self-comprehension of the community (along principles such as respect of human rights, rule of law, fairness, justice, etc.) and the experience of persons of generations alive. Following Honneth, claims for recognition which are morally legitimate or defensible must point in the direction of a societal development that we can grasp as coming closer to our notions of a good or just society (Honneth; 2004: 353). 
Claims for recognition based on personal experience find a pretension of legitimacy if they do not infringe these requirements, if they are able to fulfil the check list of conformity with high standards of human rights, rule of law, accountability. In democratic politics, furthermore, it may be assumed that claims fulfilling these normative requirements must compete for asserting themselves (at least they are already constitutionally sanctioned).

Among the possible legitimate claims for recognition in democratic polities, those of persons alive who suffered the facts as victims are particularly relevant. Todorov writes that the old victim has an unlimited right to sate his claim and demand his due; in taking up this position, he assures himself his own gratification (Todorov; 1995: 131). ${ }^{5}$ They saw their dignity violated and, taking into account repressive nature of the regimes, due process and respect of rights were conspicuously absent. Thus, the attention to victims is not only an act of justice but also an act of reasserting the basic values sustaining democratic policies. In contrary sense, claims for recognition of perpetrators cannot and do not play a role in policies of memory in democratic polities (at least they express regret, at least they may have exemplifying value or at least they can present themselves as victims).

Whilst claims for recognition deserve always attention, two caveats must be introduced. The first is that not all forms of victimhood can be equally treated: massive murder and torture represent a superior form of denigration and elimination of human dignity whilst deprivation of property or employment carries a different level of suffering. Mechanisms for dealing with these later categories of victims do not usually pass in fact mainly through politics of memory but through reparations. The second caveat refers to the eventual policy actions that may be taken: these do not derive automatically from these claims but rather they must be discussed and argued in a given political context. In democratic contexts, deliberation between publics (encapsulated in parliamentary form) mediates between claims and policies.

\subsection{Politics of memory II: The partisan use of memory}

A second dimension in which policies of memory become politics of memory refers to their use. Any policy of memory has the effect of shaping historical perceptions of the community and this is particularly important taken in combination with the selection bias mentioned above. The selection of specific memory items will condition the model of community which is meant to convey. Memory can be put at the service of a political programme for instance of nation building. And selection bias goes also for that which is not identified as part of memory: as Renan put it, forgetting, I would go as far as to say historical error, is a crucial factor in

5 Todorov warns on possible excesses linked to the temptation for anyone to identify herself with the role of victim in a long term basis, since the status has some "advantages": few material compensations but particularly, the moral claim mentioned above: in taking the position as claim maker, he assures himself on his own gratification (i.e. the right to complain). 
the creation of a nation; thus, the progress of historical studies is often a danger for national identity...the essence of a nation is that all individuals have many things in common, and also that they have forgotten many things (Ernst Renan, quoted in Judt; 2005: 803). Narratives and myths contribute to construct an element of identification with a community and, in this sense, they contribute to the creation of a sense of belonging. Müller summarises a point in which most authors would agree: national collective memory serves as a frame for nationally minded individuals to place and organize their histories in a wider context of meaning, this forming collective identity (Müller; 2004: 3). Policies of memory thus contribute to the delimitation of the borders of the perceived community and they serve to reinforce the solidarity among its members. This seems particularly evident in the case of commemorations: "commemoration activity" usually serves to strengthen the feeling of community and solidarity among those commemorating - a solidarity that is not necessarily based on consensus over the past events, but it rather extends to several generations, social classes and political events (Gillis; 1994).

Because of this identity and solidarity creating function, they are politically very attractive to flesh out specific partisan programmes. The subjective and interactive element of politics of memory implies also an emotional capability: facts which relate to their experience or the experience of their close relatives can move people. And these emotions can be used, abused and manipulated politically in a very instrumental sense, for instance, to reinforce national identity. Hence, the temptation to convert history in memory (or, in other words, activating historical facts as components of current living generations' personal experiences) may appear because of the mobilising potential of memory. Transforming historical facts into memory allows the activation of passions connected to memory. "The discourse about the past is, in many cases, only the encoded and masked form of a contemporary political debate, a proxy struggle, conducted in historical costume" (Schögel; 2004: 7). Appropriate remembrance and historical writing is based on an act of recognition of preceding generations. It is we, the living, who give the dead their voices- or refuse to; because they have fallen silent, they can only speak with our help (Schögel; 2004: 9).

Successful transformation of policies towards the past or policies of history into the more specific and also subjectively more intense policies of memory has a large premium: the moral high requirements placed on the later are invested on the former. Additionally, transformation of historical facts into memory facts activate the personal subjective dimension of memory and, in this way, it may activate the subjective components of personality such as passions. 


\section{POLITICS OF MEMORY IN THE EU PRE 2004}

As with many other institutions and policies, the reflection and design of policies of memory refers to states, something that the EU is not. The arguments for which states implement policies of memory have been implicitly exposed above. If the question is referred to the EU, explanatory arguments (responding to the question why the EU is developing some sort of policies of memory) and normative arguments (why the EU should develop them) may appear conflated.

Historically, the political context of creation of the European Communities paid smaller attention to policies of memory and, on the other hand, it had a different moral orientation than nowadays. In the aftermath of WWI (when the Union was created), Western Europe states' strategy for dealing with memory was universal neglect of Holocaust with a parallel victimization of the nation (Austrian, Belgian, Dutch nation). ${ }^{6}$ In words of Droit, social consensus in post 1945 West European societies relied very much on the myth of resistance (Droit; 2007: 203). Only in the 1960 s, a series of war crimes trials in some European states put in the forefront the memory of the Holocaust. According to Tony Judt, by the end of the XX century, the centrality of the Holocaust in Western European identity and memory seemed secure (Judt; 2005: 820). EvaClarita Onken, refers similarly two to three European memory regimes being the first two the consensus on Germany's sole guilt for the atrocities and the war and the Holocaust, and the historical myth of national resistance and victim status of all occupied countries. These two myths entailed a large scale "collective amnesia". Since the 1970s, another common unifying memory was found in the Holocaust as the singular act of barbarians, against which European unity was to be strengthened and made irreversible (Onken; 2007: 31).

The EU reflected necessarily the prevailing mood and, consequently, policies of memory did not form part of the original design of the EU in explicit terms, nor have they found their way through in the successive treaty reforms until the 2009 Lisbon Treaty. Among the very scarce EU memorialisation measures, the marking of $9^{\text {th }}$ May as the Day of Europe superposed the commemoration of the Schuman Declaration to the commemoration of the end of WWII. In this way, a myth was implicitly sanctioned: founding member states perceived the EU (the then communities) itself as a specific instrument of politics towards the past or politics of history of EU Member States: it marked reconciliation among former enemies. Just as an example, a Joint Italian-German Declaration signed in Trieste on 18 November 2008 (marking the anniversary of German invasion of Italy) argued that Italy and Germany shared the ideals of reconciliation, solidarity and integration which are at the basis of the process of construction of Europe. More importantly, the EU fulfils a key function within transitional justice paradigms: it is, in itself,

6 Equally, Hans Magnus Enzensberger writes: In the fat years after the war ... Europeans look shelter behind collective amnesic (Enzensberger; 1989). 
a guarantee of non-repetition ${ }^{7}$ of past wrongdoings, crimes and human rights abuses. Whilst some authors dispute the value of the EU as the efficient cause to explain peace among EU member states after $1945,{ }^{8}$ intellectuals ${ }^{9}$ and institutions ${ }^{10}$ have more or less explicitly assumed and endorsed this belief which has created a powerful justification for the value of integration. This foundational myth has even provided the ground for a clear and consistent attempt to use derivative myths to make sense of what the European Union does and to provide the normative and cognitive basis to see this as part of legitimate governing (della Sala; 2010: 14).

Reflecting also the evolution of its Member States mentioned above, the EU has progressively moved into policies that recognise the centrality of Holocaust. The European Parliament (EP) initiated this course from a practical dimension, dealing in several resolutions on the question of restitution of property to Jews but progressively it moved into symbolic policies. Thus, the EP demanded already in 2000 the commemoration of the $27^{\text {th }}$ of January and International Day against Fascism and Anti-Semitism (9 November anniversary of Krystallnacht; 1938). ${ }^{11}$ One year later, in a Written Declaration the EP argued that Holocaust must be forever seared in the collective memory of all peoples. ${ }^{12}$ The $60^{\text {th }}$ Anniversary of the liberation of Auschwitz marked a significant step forward: the EP approved a Resolution on remembrance of the Holocaust, anti-Semitism and racism on $27^{\text {th }}$ January $2005 ;{ }^{13}$ its President made a Solemn Statement in front of the EP and a delegation of the EU comprising the EP and the Commission plus the EU Presidency attended commemorations at the camp. At the UN General Assembly; the EU Presidencies made solemn declarations in the same sense. ${ }^{14}$ And in 2007, a German led

$7 \quad$ An explicit statement is found in Pijpers; 2006

8 Giandomenico Majone disputes the well established belief that peace is the greatest achievement of the integration process. He expresses his doubts on the causal role of European integration in this achievement and, in his view, this is largely a fiction, another instance of past hoc, ergo proper hoc, fallacy (Majone; 2009:81). He further quotes Hirschmann who writes that the EC had arrived too late to claim to have averted further wars between European countries (Hirschmann; 1981:266-284). In the same vein, Della Salla argues that for the correlation between both peace and European integration to be true, it requires to believe a certain (mythical) story of European integration (della Salla; 2010: 6).

9 Thus, Timothy Snyder wrote that the EU is, alter all, built upon the premise that totalitarianism must not return (Snyder; 2005).

10 Although not an EU institution, PACE constructed an argument on the CoE special responsibility on preventing the resurgence of Nazi ideology that may apply exactly to the EU: Modern Europe has been conceived on the basis of a total rejection of Nazi ideas and principles, to ensure that such horrendous crimes as these committed by the Nazi regime in the name of "racial superiority" will never be repeated. PACE Resolution 1495 (2006). Similar institutional narrative relates "European" architecture to Holocaust: It is in Europe that the Holocaust took place. And (...) it is out of that dark episode that a new Europe was born EU Presidency (UK) Statement on Holocaust Remembrance in the UN General Assembly $31^{\text {st }}$ October 2005; The EU, like the UE itself, was born out of the catastrophe of war and genocide. Our peoples at the time were moved by the firm resolve to never let this happen again. EU Presidency (Germany) Statement in the UN General Assembly after the adoption of the Resolution on Holocaust Denial (A/61/ L. 53).

11 EP Resolution on countering racism and xenophobia in the European Union OJ C 377/366 29.12.2000..

12 EP Written Declaration on the remembrance of the Holocaust OJ C 121/503 24.4.2001

13 PE 354.156 European Parliament Resolution on remembrance of the Holocaut, anti-semitism and racism 27th January 2005 P6_TA(2005)0018

14 See note 10 
initiative meant the approval of a framework decision penalising the denial of holocaust, in what has been termed as the "Europeanization of German memory politics" (Leggewie; 2009: 2) or "Europeanization of Holocaust" (Banke; 2010: 6).

Successive enlargements of the EU did not substantively transform this original interpretative framework. The states of the 1970s enlargement belonged to the group of continuous democracies from 1945 and their eventual issues with current members were settled before and outside the Communities. Former authoritarian regimes became members in the 1980s Mediterranean enlargement that the EU anticipated through the formulation of a strong implicit conditionality policy: Member States must be democratic and respect human rights. However, none of the three new member states brought in claims for recognition related to policies of memory which challenged the predominant narrative on the past within the EU. And, finally, the 1996 enlargement brought into the EU states whose eventual claims might be perfectly aligned with those of existing members. None of these rounds of enlargement challenged the foundational narrative of the EU and, hence, the self-understanding of the community (of states and peoples).

\section{NEW CLAIMS FOR RECOGNITION IN THE EU}

This situation changed after the 2004 Eastern enlargement. Although the EU lacked of a explicit formalised position on the issue, there was, firstly, an implicit pressure on Central and Eastern European applicants for recognition of the Holocaust as part as their policies of memory. Droit has termed this as the "Copenhagen memorial criterion": the implicit understanding that recognition of Holocaust was a sine qua non of accession (Droit; 2007; Leggewie; 2006). The argument combined the identification of a genuine neglect in which the culture of Shoah has not encountered its place in people's memorial culture in the populations of the countries of Central and Eastern Europe (Droit; 2007: 114) together with a more questionable bias in the memory policies of Central and Eastern Europe. ${ }^{15}$ Thus, Droit identifies several memorialisation initiatives which commemorate Nazi collaborators or akin-minded leaders in Bulgaria, Estonia, Romania and Slovakia. Speaking specifically about the Baltic countries, Onken denounces that in Latvia and Estonia, the local "Waffen SS Legions" are seen as freedom-fighters against the Bolsheviks and as national heroes (Onken; 2007: 34). This couples with the strong criticism of the lack of commitment to condemn and prosecute local Nazis voiced, for instance, by the Simon Wishental Centre and authors such as Judt (2005) or writers such as Katz (2010).

Simone Veil expressed strongly the views on the issue in her adresss to the Bundestag $27^{\text {th }}$ January 2004: La Shoah n'est pas encore suffisamment reconnue dans un certain nombre

15 For instance, in 2003, the local municipality of Pärnu inaugurated a monument to the Estonian SS Unit in the premises of the local graveyard. Under pressure from EU states, no member of the government attended the ceremony (Droit; 2007) 
de pays d'Europe de l'Est : manipulé par les régimes communistes longtemps au pouvoir, le souvenir des souffrances infligées par l'occupant nazi aux peuples occupés a oblitéré le souvenir des souffrances infligées aux Juifs, avec parfois la complicité de ces peuples. Dans les pays d'Europe de l'Est désormais libérés du joug communiste, d'autres souvenirs-écrans viennent à présent recouvrir le nécessaire travail de mémoire sur la Shoah : pour ces peuples soumis pendant presque un demi-siècle à la domination soviétique, les victimes du communisme ont effacé celles du nazisme. Plus grave, la mémoire et l'histoire sont parfois manipulées au point de servir à justifier l'antisémitisme par la référence aux souffrances infligées par les soviétiques. Au moment où l'Europe s'élargit à l'Est, il faut s'alarmer de ces dérives, car ces apparentes controverses historiques touchent en profondeur à l'identité de l'Europe future. ${ }^{16}$

Some Central and Eastern European countries and/or constituencies perceived this requirement of recognition as an imposition (Droit; 2007:107; Banke; 2010: 8) and it also challenged the national memory policies of some applicants. Baltic countries, in particular, had successfully established the collective memory of national "suffering and heroism" as the dominant memory regime and, in 2004, they were suddenly confronted by an historical memory that stood in stark contrast to the historical image of their own nation as the eternal victim of great European powers (Onken; 2007: 31 and 33). Some of these perceptions may apply also to other Central and Eastern European countries ${ }^{17}$ and whilst they felt into line with the European (in general) and EU (in particular) policies, there was also a reaction. ${ }^{18}$

The overarching claim, in a nutshell, is one of equal recognition: in the view of its proponents, the dominant narrative on European history (as reflected by education, symbolic practices and awareness initiatives) reflects predominantly (and for some only exclusively) the experiences of the Western part of the continent whilst the historical experience of central and Eastern European countries has not been included. Thus, citizens, intellectuals and politicians from Central and eastern European countries demand the recognition of their facts of memory. In some cases, these arguments have been very crudely put and constructed as a questioning of existing Western-perceived narratives and challenging broadly accepted claims for recognition. Thus, leaders and populations in Central and Eastern Europe have occasionally not hesitated in engaging on an explicit or implicit comparison of the violence suffered by them under the

16 Discours de Mme Simone Veil devant le Bundestag, Berlin, 27 janvier 2004 www.fondationshoah.info/ FMS/DocPdf/Discours/FL\%20Discours\%20Berlin.doc

17 The Hungarian anthem contains a line that says: God Bless the Hungarians (...) Torn by misfortune for long,(...) These people have expiated the past and the future.

18 It must be recalled that the strategy of claims making does not target exclusively the EU but it comprises also the Council of Europe and the OSCE. As an example, the Parliamentary Assembly of OSCE approved as part of its Vilnius Declaration in July 2009 a Resolution on divided Europe reunited: Promoting Human Rights and civil liberties in the OSCE region in the $21^{\text {st }}$ century http://www.oscepa.org/images/stories/documents/activities/1. Annual\%20Session/2009_Vilnius/Final_Vilnius_Declaration_ENG.pdf 
Soviet regime with the Shoah. Thus, in a well published speech at the Leipzig Book Fair on 24rd March 2004 (barely a month before becoming EU Commissioner), Latvian politician Sandra Kalniete argued the thesis that both regimes (i.e. Nazi and Communist) are equally criminal. Hence, it must therefore not exist difference between these. These words provoked the walk out of the Vice-Chairman of the Central Jewish Council in Germany, Salomon Korn because they were considered as underlying the suffering of her compatriots under Soviet domination without calling into question Latvian participation in the extermination of Jews between 1941 and 1944. Some have interpreted this kind of attitudes as a relativization of the Holocaust and a parallel silencing of the role of these states and populations in it (Katz; 2010). ${ }^{19}$ Additionally, it has been perceived as an attempt to minimize the suffering under the Shoah and refusing to grant the statute of victims to Jews. ${ }^{20}$

This "equally criminal" claim had a number of specific derivations, the first being the official institutional condemnation of the communist regimes. Thus, a number of European countries have condemned the communism (in similar way to the condemnation of Nazism and Fascism after WWII). From this, the familiar pattern of Europeanization via transference to the upper level of the governance system can be identified: actors transfer their national claims into a higher level. Thus, in 2000, Bulgaria approved a Law for Declaring the Communist Regime as Criminal. Immediately after, members of the ruling party at the European People's Party (EPP) in the Parliamentary Assembly of the Council of Europe (PACE) pushed for the acceptance of a similar resolution from the EPP. Following an initiative by Bulgarian representative Lachezar Toshev, the EPP adopted a Report with the official title "The Need of International Condemnation of Totalitarianism" during its XVI Congress (4-5 February 2004) with the support of Hungarian and Baltic deputies in the PACE and the support of French (Stephane Courtois) and other intellectuals (the Russian dissident Vladimir Bukovsky). The EPP resolution called for the establishment of an independent expert institution to gather and evaluate information, related to violation of human rights during the period of totalitarian communism. The EPP initiative (sponsored by Swedish Member of PACE, Göran Lindblad) led to the adoption of PACE resolution № 1481 on 25 January 2006, which called for the condemnation of the repressive communist system, established by the Soviet Union in Eastern Europe after World War II. Supporters of the report came from a wide spectrum of ideological background (both members of the socialist group

19 For a more nuanced approach referred to the Hungarian case, see Sajó; 2005.

20 Nevertheless, there are clear cases of recognition of Holocaust in some Central and Eastern European countries. Thus, in 2009, the Czech Presidency of the EU promoted a Holocaust Era Asses Conference which approved the Terezin Declaration. This declaration encouraged, inter alia, to establish and support research and education programs about the Holocaust (Shoah) and other Nazi crimes, ceremonies of remembrance and commemoration, and the preservation of memorials in former concentration camps, cemeteries and mass graves, as well as of other sites of memory.

http://www.holocausteraassets.eu/program/conference-proceedings/declarations/At the same time, the Czech government proposed the creation of a European Shoah Legacy Institute in Terezin. From the standpoint of bearers of pre-existing claims, l'imperatif mémoriel est-européen est justifié, a condition que cette exigence ne se tourne pas contre le consensus oust-européen, (words of Samuel Korn quoted in Droit; 2007: 119). 
and the EPP) and argued on the need to morally assess and unambiguously condemn the crimes committed by the totalitarian communist regimes in Central and Eastern Europe. Members of communist parties (Russian inter alia) accused supporters of the report of biased approach and blind anti-communism. PACE Resolution 1652 (2009) repeated the condemnation of dictatorial regimes such as National Socialism, fascism and totalitarian communism. In contrast with these initiatives in the Council of Europe, claims from other EU Member States have aimed at EU institutions; thus, Spanish political parties requested and obtained from the EP a Declaration of condemnation of the Franco regime ${ }^{21}$ in 2006 . This followed a previous PACE Resolution on the need for international condemnation of the Franco regime. ${ }^{22}$

A second derived claim refers to the criminalization of the denial of the so-called totalitarian crimes. On 19 April 2007, the Council of Ministers approved the Framework Decision "on combating certain forms and expressions of racism and xenophobia by means of criminal law" which seeks to ensure that the same kinds of racist and xenophobic behaviour are punished in all the Member States. Politicians from some new Member States presented the argument that the crimes of Soviet communism should be equally treated. More precisely, former Lithuanian President Vytatutas Landsbergis raised the issue in the EP where it met the opposition in particular of former Italian communist. Nevertheless, the Decision included an invitation from the Council to the Commission to examine and to report to the Council within two years after the entry into force of the Framework Decision whether an additional instrument is needed, to cover publicly condoning, denying or grossly trivializing crimes of genocide, crimes against humanity and war crimes directed against a group of persons defined by other criteria that race, colour, religion, descent or national or ethnic origin. The Commission position was that it was up to each country to find its own way deal to with the memory of totalitarian crimes, meet the expectations of the victims and their descendants and achieve reconciliation. For the Commission, the European Union cannot stand in for the Member States in this process. Apart from its role in setting an example of reconciliation, the European Union has little power to act in this field. Its role can only be to facilitate the process by encouraging discussion, promoting the exchange of experience and good practices and bringing the different stakeholders together. Nevertheless, the Stockholm Programme approved in December 2009 invited the Commission, in line with these claims, to examine and to report to the Council in 2010 whether there is a need

2170 years after General Franco's coup d'état in Spain - (Statements by the President and the political groups) Official Journal of the European Union C 303 E/17 13 December 2006

22 PACE Recommendation 1736 (2006). The PA called the Committee of Ministers to adopt a declaration of condemnation and to mark the 18 July 2006 as the official day for condemnation of the Franco regime. PACE also called the Spanish government to create a national committee to investigate human rights violations; to continue making accessible archives that may lead to truth finding; to set up a permanent exhibition at the underground of the Valley of the Fallen and to locally erect memorials to victims. The Committee of Ministers replied condemning the repeated violations of human rights but rejected singling out one regime rather than other since this might give the impression that some totalitarian regimes are worthier of condemnation that others. Consequently, the Committee believed that all totalitarian regimes without distinction should be made the object of such a declaration 
for additional proposals covering publicly condoning, denying or grossly trivializing crimes of genocide, crimes against humanity and war crimes directed against a group of persons defined by reference to criteria other than race, colour, religion, descent or national or ethnic origin, such as social status or political convictions.

A third claim refers to the recognition of commemoration dates which are linked to facts of memory of Central and Eastern European countries. Several initiatives mentioned above (backed by other additional international instruments) ${ }^{23}$ have officially placed $27^{\text {th }}$ January as a commemoration date for the EU. Mirroring this move, MEPs from ex-communist countries sponsored an additional commemorative date which would take into account also the victims of Soviet terror. Thus, on $2^{\text {nd }}$ April 2009 the European Parliament adopted a resolution on European conscience and totalitarianism which set the date of 23 August (the date on which in 1939 the infamous Ribbentrop-Molotov agreement was signed between Nazi Germany and the Soviet Union) as the commemoration date. The Resolution called inter alia for "the proclamation of 23 August as a Europe-wide Day of Remembrance for the victims of all totalitarian and authoritarian regimes." So far, Estonia, Latvia, Lithuania, Slovenia and Sweden have adopted this date as a day of remembrance.

A fourth claim projects into the teaching of history integrating Central and Eastern European perspectives. The elaboration of common textbooks and, more ambitiously, proposals for some form of "common history" definition are a constant attempt. Baltic MEPs sponsored a study on Reunification of European History ( $8^{\text {th }}$ June 2006 at the EPP group at the EP). The aim was to overcome the mental barrier created between Eastern and Western Europe. In 2007, the German Presidency of the EU proposed a common history book for secondary education. Whilst the Commission adopted a cautious approach on the topic, the European Association of History Teachers (EUROCLIO) endorsed enthusiastically the proposal arguing that a nationcentric approach still dominates history teaching leading to poor understanding of shared and common experiences. ${ }^{24}$ The PACE Resolution 1652 (2009) on attitude to memorials exposed to different historical interpretations in Council of Europe member states set the CoE policy. The PACE affirmed its belief that disputes related to divergent interpretations of history can only be resolved with time through a process specific to each nation.

23 Resolution 60/7, the UN General Assembly on 1 November 2005 resolved that "the United Nation will designate 27 January as an annual International Day of Commemoration in Memory of the victims of the Holocaust". Previously, a Declaration by the Ministers of Education of the Council of Europe (18 October 2002) called to establish in close cooperation with the Council of Europe a "Day of Remembrance" in member states' schools, as from 2003, according to national practice and priority.

24 http://www.euroclio.eu/site/. Euroclio's overall aim is to promote and support the development of history education so that it strengthens peace, stability, democracy and critical thinking runs several projects with different geographical and thematic areas. In 2009, it launched an inquiry on the teaching of common European history whose results will be presented to the Annual Conference in Nijmegen, the Netherlands on March 22-28 2010. 
A fifth claim refers to memorialisation policies. The PACE Recommendation 898 (1980) suggested the conservation of "monuments set up by invaders or by a regime regarded as oppressive or hated" in museums as an alternative to their demolition. The PACE Resolution 1652 (2009) on attitude to memorials exposed to different historical interpretations in Council of Europe member states set the CoE policy. The fate of memorials in a sovereign decision of the state in which a monument is located although based on the norms of international conventions and bilateral agreements. PACE emphasises the need for deeper and mutual understanding and conciliation action to prevent memorials of disputed symbolic significance becoming a source of tension in intra-state relations. PACE Recommendation 1859 (2009) requested the creation of a common European database of war graves and memorials located in CoE member states. Where graves and burial sites containing the remains of foreign soldiers and war victims are concerned, national decisions must fully abide by the respect for the dead, often victims rather than occupiers, and bilateral or multilateral agreements, notably the Protocol I to the Geneva Convention. The same Recommendation suggested the creation of a European centre of expertise for helping member states with historiographical and archaeological investigation. These claims have progressively moved into the EU: Following an amendment in the EP, the 2007-2013 Programme "Citizens for Europe" included a new action 4 for the preservation of European memory. It referred specifically to the preservation of memorial sites related to Nazi and Stalinist deportation and mass extermination which was originally included in the 2007 Culture Programme. Some authors recall, however, the Western aloof attitude towards Eastern memorialisation policies. Thus, the removal of a Soviet memorial in Estonia did provoke a crisis with Russia which nevertheless did not spelt into an EU-Russia crisis, "an indication of how little the EU felt involved in the events" (Leggewie; 2009).

Central and Eastern European states have sponsored a number of meetings and conferences in which these claims have been aired. Thus, on 8 April 2008, the Slovenian Presidency organised a hearing with the title "Crimes committed by totalitarian regimes". Proceedings were published with a document signed by some participants. On March 2009, the Czech Presidency, in collaboration with the ISTR organised a public hearing in the EP on "European conscience and crimes of totalitarian communism". The conclusions called for the establishment of a Platform of European Memory and Conscience which would provide support for cooperation among national institutes specialising in the subject and would also help in increasing awareness on crimes committed by totalitarian regimes. They also called for the creation of a pan-European documentation centre/memorial for victims. On October 2009, the Lithuanian government sponsored an International conference at the seat of the EP with the title Europe 70 years after the Molotov-Ribbentrop Pact among whose objectives were to elaborate on how to achieve an honest and open appraisal of common European totalitarian legacy of the $20^{\text {th }}$ century, to ensure indiscriminate treatment to all crimes of genocide, crimes against humanity and war crimes, as well as to their victims and to discuss possible strategies with a view to increase knowledge 
and public awareness about the European totalitarian legacy of the $20^{\text {th }}$ century, thus helping to prevent strengthening of intolerance, extremism and the recurrence of totalitarian rule in the future. $^{25}$

The repertoire of claims for recognition is not by any means closed: it can not be discharged that future EU member states may introduce new claims for recognition related to their own experiences (for instance, the Balkans applicants may bring with them significant claims in this domain). In 2006, the EP asked Turkey to recognise the Armenian genocide hinting that it could eventually become a precondition for accession. Although the issue has never been an explicit condition for accession, some Member States have advanced parliamentary resolutions in this direction which may create burdens and, thus, implicitly they may turn into an accession requirement. ${ }^{26}$

In summary, the new emerging claim coincides around a demand for a new narrative that accepts that during four decades eastern Europeans had to experience communist subjugation rather than European integration (Snyder; 2005: 3). ${ }^{27}$ This claim contains also an implicit challenge to traditional narratives of European integration in which Eastern Europe provided a powerful counter-referent: the issue of the Cold War as a driving force behind the integration of Western Europe was hardly ever addressed directly. The idea of peaceful co-operation in the West was more or less derived from visions of eternal peace built on the ruins of World War II, and in opposition to the suppression of democracy in the East (Stråth; 2005: 265).

\section{STRUGGLING FOR RECOGNITION: A NORMATIVE ARGUMENT FOR EU POLICIES OF MEMORY}

All these claims, petitions and demands show a transformation of the traditional perception of European institutions in general and the EU in particular. They show that actors conceive increasingly the EU as a relevant site for recognition of identity and rectification of injustice and they aim their claims to the Union. As far as policies of memory goes, the EU is increasingly becoming a recognition order, a framework within which individuals and groups are learning to see themselves recognised with respect to certain categories. ${ }^{28}$

The emergence of a struggle for recognition of claims means that memory has entered EU

25 In December 2004, some Baltic MEPs tried to gather signatures for a draft declaration condemning the Molotov-Ribbentrop pact. Yet, they failed to get the sufficient number of MEPs signatures (Onken; 2007: $43 \mathrm{fn}$ 33).

26 French Assembly has adopted a Resolution and the British parliament is currently discussing a Bill to introduce a national day to learn about and remember the Armenian genocide http://services.parliament.uk/ bills/2009-10/armeniangenociderememberanceday.html

27 Some central European historians blame Member States and the EU itself for their role in the 1989 transitions to democracy. Thus, the threat of regional chaos and residual fear of German hegemony meant an overwhelming support for preserving the status quo as the events of 1989 unfolded (Borhi; 2009).

28 I follow for this theoretical view on recognition in the EU Fossum, 2005 who elaborates from Honneth; 
politics. Whilst the EU was born in specific historical circumstances which did not create a suitable framework or conveying to the EU level claims for recognition of memory related issues, Central and Eastern Europe enlargement and the specific environment in which it happened (with a robust acquis of practices in policies of memory across the world and even within European states) changes this framework. Enlargement introduces new issues which modify what Claus Offe called the "hegemonic" configuration of issues (i.e. those that deserve priority in each society and in respect to which political success or progress is primarily measured, while others are marginal or "outside" of politics (Offe; 1987: 66).

With enlargement, citizens, groups, social movements, and states come with expectations and hopes, and with a history of structured expectations of recognition and of recognition denied (Fossum; 2005: 140). Among these, a prevalent expectation for recognition among constituencies of new Member States refers to their differential perception of European events after 1945 and the elements that may enter a common European memory. These can be constructed and/or perceived as conflicts but, as Hirschmann rightly argues, conflicts refer to notions of justice. In societies with freedom of speech and association, concerns about (newly emerging inequalities and sectoral or regional declines) tend to mobilise both those who are immediately affected as well as citizens who are sensitive to more or less widely shared feelings about social justice. Here, there arise demands for corrective action and reform, demands that are based both on selfinterest and genuine concern for the public good. (Italics in the original) (Hirschmann; 1994: 212).

Hence, arguments of justice impede rejecting that the EU may become a site for conflict and, eventually, recognition of politics of memory: Withholding some recognition held to be legitimate is a source of social injustice (Honneth; 2004: 352). In the view of its members, societies represent legitimate order structures only to the degree that they are in a position to guarantee reliable relations of mutual recognition at various levels (Honneth; 2004:354). Functionally, access can help to settle claims and, conversely, denial of access or strong biases in access can exacerbate recognition problems, as claimants can come to see lack of access as a denial of recognition (Fossum; 2005: 138).

What makes the EU the legitimate community for recognition of claims? One argument builts on the idea of shared guilt (i.e. all European states took part in the Holocoaust (Pijpers; 2006). In this sense, there might be a differential attitude to the claims coming from former Soviet regimes: la communauté de mémoire des victimes du national-socialisme comprend toute l'Europe alors que l'URSS n'a soumis que l'Europe de l'Est à sa terreur et a sa domination (Droit; 2007: 105). Apart from the accuracy of the description, this argument relies on the notion of "extended responsibility" which is intuitively consistent with intuitive notions of community. De Greiff, nevertheless, has identified a substantial weakness from the theoretical point of view: the difficulty to morally transfer debts between generations and, what is more 
important, how the dead can be proper recipients of present obligations (de Greiff; 2002: 22). A second criticism adds weight to this: how moral obligation can travel through space? De Greiff proposes an alternative foundation of the "duty to remember" (which can be extended to policies of memory) which is based on the notion of trust: the duty to remember is justified because is a way to gain the trust of these whose ancestors were victimised. The duty is thus towards our fellow citizens, it is a duty towards the present. This scheme fits with the current configuration of the EU community: Even without being a national community, the EU is a community of citizens constructed around rights and duties as defined by the statute of EU citizenship and the requirements of pertinence to the EU: respect for human/fundamental rights and democracy. As de Greiff rightly argues, interpersonal trust is essential for the cooperation with strangers that is a pre-requisite for large scale political organisation on which modern democracies are bases (de Greiff; 2002: 28). Trust translates also as feeling of inclusion: it (may) be very hard for East Europeans to believe that they are full partners in Europe so long as their experiences in the second half of the twentieth century are not part of a larger European story (Snyder; 2005: 3). In words of Vytautas Landsbergis, Recognition of the suffering of nations under communist totalitarian dictatorships is essential if wounds are to be healed. Spanish former communist and Buchenwald concentration camp survivor Jorge Semprún in his Discourse at the Weimar National Theatre at the $60^{\text {th }}$ anniversary of the liberation of the camp argued that EU enlargement could only succeed both culturally and existentially "when we have shared and united our memories".

The argument emerging is that claims for recognition cannot be ignored because of reasons of justice and, hence, policies of memory going beyond the current status quo in the EU may be required. Policies, though, are not an automatic result of claims. Claims for recognition do not imply automatic acceptance of the consequences that claimants associated to them. Rather, claims have to be received, grounded in the addressed community and, after the process of subjective interaction that recognition requires, policies will appear as response to the interaction. This is particularly important when states are the claim makers: accepting the legitimacy of their claims for recognition does not imply automatic acceptance of the policy proposals associated to these claims. The identification of the EU as a site for recognition of claims does not spare the requirement of the intersubjective assumption of claims. Claims for recognition within the EU have to be debated by individuals if they are to be effectively recognised. Now, the EU has an imperfect public sphere and deliberation of citizens on these kin of claims cannot be realistically expected. The proxy for this intersubjective deliberation is of course, institutional debate and discussion, out of which eventually a policy of memory may emerge. 


\section{Conclusion}

The EU is emerging as a site for addressing claims for recognition of memories coming from different historical experiences. Arguments of justice based on the construction of trust with fellow citizens support the pretension of legitimacy of these claims. Hence, there are grounds to claim that the EU may have to address the issue of what kind of policies of memory are necessary in order to successfully integrate all legitimate claims for recognition. The Union has quite a few instruments (plus some additional ones within the Council of Europe) which, without being specifically designed as policies of memory can nevertheless fulfil the role of recognition policies. 


\section{REFERENCES}

1. Aguilar, P. (2008) Políticas de la memoria y memoria de la política (Madrid: Alianza Editorial)

2. Banke, Cecilie Felicia Stokholm (2010) The Legacies of the Holocaust and European Identity after 1989 DIIS Working Paper 2009:36 January, 14 p.

3. Borhi László (2009) A reluctant and fearful West. 1989 and its international context The Hungarian Quaterly 196. Available at http://www.eurozine.com/articles/2009-11-06-borhi-en.html

4. De Greiff, Pablo (2002) The duty to remember: the dead weight of the past or the weight of the dead of the past?

5. Della Sala, Vincent (2010) Political myth, mythology and the European Union Journal of Common Market Studies vol. 48 No. 1 pp. 1-19.

6. Droit, Emmanuel (2007) Le Goulag contre la Shoah. Mémoires officielles et cultures mémorielles dans l'Europe élargie Vingtième Siècle. Revue d'histoire 94 p. 101-120

7. Enzensberger, H.M. (1989) Europe, Europe: Forays into a continent (New York, Pantheon Books)

8. Fossum, J.E. (2005) Conceptualizing the EU's social constituency European Journal of Social Theory 8(2): $123-147$

9. Gillis, John R. (ed.) (1994) Commemorations: The Politics of National Identity (Princenton: Princeton University Press)

10. Judt, T. (2005) Postwar. A History of Europe since 1945 (Penguin Press HC, 2005)

11. Hirschman, A. O. (1981) Three uses of political economy in analyzing European integration, in Hirschman, A. O. Essays in trespassing (CUP)

12. Hirschman, Albert O. (1994) Social conflicts as pillars of democratic market society Political Theory Vol.22 No. 2 pp. 203-218

13. Honneth, A. (2004) Recognition and Justice: outline of a plural theory of justice Acta Sociologica 47(4) pp. 351-364

14. Katz, Dovid (2010) Halting Holocaust obfuscation The Guardian Friday 8 January

15. Leggewie, Claus (2006) Equally Criminal? Totalitarian Experience and European Memory", in Eurozine, www.eurozine.com/articles/2006-06-01-leggewie-en.html

16. Leggewie, Claus (2009) Battlefield Europe. Transnational memory and European identity http://www. eurozine.com/articles/2009-04-28-leggewie-en.html

17. Majone, G. (2009) Europe as a would-be power Cambridge, Cambridge University Press

18. Müller, Michael G. (2004) The Joint Polish-German Commission for the Revision of School Textbooks and Polish views on German History German History Vo. 22 no. 3 pp. 432-447

19. Müller, Jan Werner (2004) Introduction: The power of memory, the memory of power and the power over memory, in Jan-Werner Müller (ed.) Memory and Power in Post-War Europe Studies in the Presence of the Past (Cambridge: CUP)

20. Onken, Eva-Clarita (2007) The Baltic States and Moscow's 9 May commemoration: analysing memory politics in Europe Europe-Asia Studies vol. 59 no. 1 pp. 23-46

21. Offe, Claus (1987) Challenging the boundaries of institutional politics: social movements since the 1960s, in Charles S. Maier (ed.) Changing boundaries of the political: essays on the evolving balance between the state and society (Cambridge: Cambridge University Press)

22. Pijpers, Alfred (2006) Now we should all acknowledge our holocaust guilt Europe's World no. 4 pp. 124-127

23. Schlögel; Karl (2009) Places and strata of memory. Approaches to eastern Europe Osteuropa 11/2009. Available at http://www.eurozine.com/articles/2008-12-19-schlogel-en.html

24. Snyder, Timothy (2005) Balancing the books www.eurozine.com 
25. Snyder, T. (2004) Memory of sovereignty and sovereignty over memory; Poland, Lithuania and Ukraine since 1939, in Jan-Werner Müller (ed.) Memory and Power in Post-War Europe Studies in the Presence of the Past (Cambridge: CUP)

26. Stråth Bo(2005) Methodological and Substantive Remarks on Myth, Memory and History in the Construction of a European Community German Law Journal Vo. 6 no. 2 pp. 255-271

27. Todorov; Tzevan (1995) Communist camps and their aftermath Representations 49 pp. 120-132 
1. Cruz Castro, L. y Sanz Menéndez, L. Endogamia, Productividad y Carreras Académicas.

2. Corrochano, D. Guía Bibliográfica sobre Inmigración en España (1990-2009). Datos y Reflexiones sobre la Institucionalización de una Comunidad Académica.

3. Golob, S.R. Evolution or Revolution? Transitional Justice Culture Across Borders.

4. Arias Aparicio, F. Organización y Producción del Conocimiento Científico en los Organismos Públicos de Investigación Agraria: El Instituto Nacional de Investigación Agraria y Alimentaria (INIA).

5. Moreno, L. Welfare Mix, CSR and Social Citizenship.

6. Martínez, C. \& Rama, R. The control and generation of technology in European food and beverage multinationals.

7. Del Pino, E. \& Colino, C. National and Subnational Democracy in Spain: History, Models and Challenges.

8. Closa, C. Negotiating the Past: Claims for Recognition and Policies of Memory in the EU. 